\title{
The Spiritually-Guided Enterprise: Setting A Course Of Study
}

Darlene B. Smith, (E-mail: dsmith@loyoal.edu), Loyola College in Maryland

Ellen D. Hoadley, (E-mail: ehoadley@loyola.edu), Loyola College in Maryland Ronald Desi, (E-mail: desi@loyola.edu), Loyola College in Maryland

\begin{abstract}
This paper begins an exploration of the intersection between Christianity and business with a focus on the spiritually-guided enterprise. It examines the impact of Christian leadership on business and seeks to explore whether Christians run their businesses differently. The purpose is to pose reflective questions that will indicate potential research studies and that will lead to a greater understanding and knowledge of this intersection.
\end{abstract}

\section{INTRODUCTION}

$T$

he 2004 national elections provided an interesting commentary on the cultural state of the United States. As stated by Adrian Dix (2004) of CBS News Viewpoint: For a part of the electorate that is outside of the elite mainstream, the campaign was transformed into an evangelical revival meeting. For example, in 11 states, including Ohio, there were referendums banning gay marriage, all of which passed with resounding majorities. In Florida, the swingiest of swing states, a referendum forcing young women to seek parents' consent to have an abortion inspired many direct voting appeals from Catholic and Evangelical pulpits.

No matter where you stand on the issues politically, the outcome of the election prompts certain questions. To what extent do religious values in general, and Christian values specifically, affect our public lives? To what extent are these same values at work within our business organizations? What is the impact of Christian leadership on business and the economy? Do Christians run their businesses differently? If so, how and why?

This paper begins an exploration of the intersection between faith, Christianity spirituality and business with a focus on the spiritually-guided enterprise. The purpose is to pose reflective questions that will indicate potential research studies and that will lead to a greater understanding and knowledge of this intersection. As all good research, this exploration begins with the existing literature.

\section{LITERATURE}

There is a growing stream of research, articles and books exploring spirituality and religion in organizations. Books -- such as Bolman and Deal's (2001) Leading with Soul: An Uncommon Journey of Spirit and Lowney's (1993) Heroic Leadership -- have been widely read among corporate executives. Furthermore, recent special issues of the Journal of Organizational Change Management, the Journal of Management Education and special sections in the Journal of Management Inquiry attest to growing interest in the topic within the academic community.

Interestingly, while the attention to workplace spirituality is growing, there is debate as to what exactly the term "spirituality" means. Krishnakumar and Neck (2002) found that despite multiple views of workplace spirituality, the key benefits of encouraging spirituality within a firm include enhanced creativity, honesty and trust, personal fulfillment and commitment - all leading to better work performance and a friendlier corporate world. Based on the belief that spirituality has a legitimate role to play in the workplace, Mitroff and Denton (1999) sought to chronicle the moves of many leaders to incorporate spiritual and religious principles into the management of their organizations. In their book, A Spiritual Audit of Corporate America, Mitroff and Denton (1999) reveal that 
organizations that encourage spirituality experience higher profits and success and, in some cases, outperform others by 400-500 percent in terms of net earning, ROI, and shareholder value. According to Mitroff and Denton (1999, p. 91), "[n]o organization can survive for long without spirituality and soul." They found that many organizations recognize the hunger for a spiritual dimension in the lives of their employees and identified five different models for fostering that spirituality: the Religious (i.e., Christian) Based Firm, the Evolutionary Firm, the Recovering Organization, the Socially Responsible Firm, and the Values-Based Company.

Up until recent times, spirituality was evident in one's religious practice. Today, however, spirituality in a broad sense is defined as the "pursuit of harmony in oneself and in one's relationship with others" and is seen as abstract from any specific religion (Kennedy 2003, p. 86). Kennedy, however, postulates that some religious traditions - most notably Judaism and Christianity — constitute a far superior basis for spirituality than other religions. Furthermore, he suggests that a Christian manager, whose life is formed by a faith commitment, should attempt to shape the workplace according to the insights of his or her faith. He advocates some specific duties for Christian managers stating that they "should be powerfully aware that all the persons associated with the enterprise - customers, employees, investors, creditors, and so on-- are individuals beloved of God and destined for eternal life." (Kennedy, 2003, p. 90)

This philosophy is shared by Ibrahim et al. (1991) in their study of Christian companies. These companies claimed that they actively combined their business activities with biblical principles. Ibrahim et al. explored the interactions of the Christian companies with their customers, suppliers, employees, and the community to determine whether there were consistent business activities that these companies shared. The study also examined whether the distinct activities differed by industry. The findings of this study (see Exhibit 1 for a summary) indicate clear defining differences found in the surveyed companies identifying specific behaviors that they exhibited toward their stakeholder groups. However, only the relationship with employees was consistent across all the companies. Interestingly, this study did not address whether the activities were different from those engaged in by more secular companies.

\section{POPULAR PRESS}

Beyond the academic literature, doing business from a Christian perspective has found a voice in the popular press. Steven Covey, in his book the Seven Habits of Highly Effective People, offers seven guiding principles to produce good results, all of which are implied in Mormon theology. Covey's (1990) habits, consisting of attitude, skill and knowledge are derived from a set of principles that include integrity, humility and fidelity. The seventh of these habits, "sharpening the saw", includes spiritual renewal, which he identifies with the "continual clarification of value commitment to others".

Larry Julian (2002) articulates ten issues facing business leaders today in God is My CEO. He provides biblically-based responses to each issue. Of particular interest is that one of the principles deals specifically with employee relationships, and a second principle deals with the other relationships between people and the business. This reflects congruence with the academic literature that Christian-based companies have different perspective on the employee relationship.

David L. Steward (2004) in Doing Business by the Good Book provides fifty-two lessons on success straight from the Bible. These lessons stem from his personal mission to serve others through his business. Steward sees his leadership role as making it possible, even probable, for others to succeed. He believes that this perspective will reach his customers, suppliers, and community through his employees. As founder and CEO of World Wide Technology, a billion-dollar company headquartered in St. Louis, Steward shares a Bible passage for each week of the year with the expectation that the company will increase its bottom line and the employees will grow spiritually. This is a direct reflection of the survey findings of Ibrahim et al. (1991). 
- Law of Responsibility - to whom much is given, much is required.

- Law of Unity - together, in agreement, we can do more than individually

- Law of Reciprocity - if you're given resources to flow through you to help others around you, you'll be given even more resources to share.

Ongoing sessions weave these principles into the Curves corporate culture and the expectations of how franchisees will sustain their relationships with customers, suppliers, employees, and the community.

\section{RESEARCH QUESTIONS}

The academic and popular literature as well as models from specific business personalities leads us to believe that Christian-based companies are different from secular companies. The following is a list of questions that would further clarify the differences.

1. To what extent and how do self-identified "spiritual" CEOs/Presidents extend their faith into their organizational culture?

2. What are the perceptions of suppliers, employees, customers, and the community of these differences?

3. Do employees in these firms feel a greater sense of community?

4. Why do some organizations market and identify their Christian foundation and others do not, even though they may self-identify as Christian or spiritual?

5. Does technology play a role in extending the corporate culture and/or relationships with customers, suppliers, and employees? Does technology support a different style of communication that further supports the culture?

\section{WHAT'S NEXT?}

What are differences between Christian-based organizational cultures and others? A survey will be conducted among organizations of both types. The findings will identify those characteristics and practices that differentiate between the spiritually-guided and secularly-guided enterprise. These findings will then lead to more specific examination of the cultural differences.

\section{REFERENCES}

1. Beckett, John D. (2001), Loving Monday, Downer's Grove, IL: InterVarsity Press.

2. Bolman, Lee C. and Deal, Terrence E. (2001), Leading with Soul: An Uncommon Journey of Spirit. San Francisco: Jossey-Bass.

3. Covey, Steven R. (1989), The 7 Habits of Highly Effective People. New York: Simon \& Schuster Company

4. Dix, Adrian (2004), Four More Years, CBS News Viewpoint; www.cbc.ca/news/viewpoint/ vp_uselection/dix_20041103.html, November 3.

5. Ibrahim, N. A., Rue, L. W., McDougall, P. P., and Greene, G. R. (1991), Characteristics and Practices of Christianbased Companies, Journal of Business Ethics; Vol. 10, No. 2 (February), pp. 123-132.

6. Julian, Larry (2002), God is my CEO, Avon, MA: dams Media Corporation Lowney, Chris (2003), Heroic Leadership. Chicago, IL: Loyola Press.

7. Kennedy, Robert G., (2003), Spirituality and the Christian Manager, in Business, Religion and Spirituality, edited by Oliver F. Wiliams. Notre Dame, IN: University of Notre Dame Press.

8. Krishnakumar, S. and C. P. Neck (2002), The what, why and how of spirituality in the workplace, Journal of Managerial Psychology, Vol. 17, No., pp. 153-164.

9. Mitroff, I. I, and Denton, E.A. (1999). A Spiritual Audit of Corporate America: A Hard Look at Spirituality, Relgiion, and Values in the Workplace. San Francisco: Jossey-Bass.

10. Steward, David L. (2004). Doing Business by the Good Book: 52 Lessons on Success Straight from the Bible. New York: Hyperion. 